\title{
THE ROLE OF USER ENGAGEMENT IN ELECTRONIC WORD-OF-MOUTH AND ONLINE PERFORMANCE
}

\author{
Achilleas BARLAS ${ }^{1 *}$, Yeoryios STAMBOULIS ${ }^{2}$, and Alkiviadis VLEIORAS ${ }^{3}$ \\ ${ }^{1}$ University of Thessaly, Department of Economics; abarlas@econ.uth.gr, ORCID: 0000-0002-8266-0138 \\ ${ }^{2}$ University of Thessaly, Department of Economics; ystambou@econ.uth.gr, ORCID: 0000-0003-0122-4404 \\ ${ }^{3}$ University of Thessaly, Department of Economics; avleioras@uth.gr, ORCID: 0000-0001-8150-5948 \\ * Correspondence author
}

\begin{abstract}
Being a member of social media channels involves the use of many engagement activities, including reposting content, commenting on posts and expressing interest. Online user engagement has been proposed to encourage various positively-valenced interactions between consumers and online brands, with electronic Word-Of-Mouth being one of the most significant. Despite the extensive research that has been carried out in the field of social media, the number of quantitative studies exploring the effects of the various factors that affect the performance of a social media channel is still limited. This study examines the relationship between online user engagement and eWOM, also addressing the effects on user interaction advertisement results. The data set was provided by a large YouTube music channel and, in contrast with other similar studies, the data extracted from YouTube analytics that represent actual user values. All insights were selected from a 6-year period. During this time, almost 500 music videos were uploaded. In total, 83831 subscribers were included in the data set. Statistical analyses showed that user engagement significantly affects eWOM. Accordingly, the role of eWOM in organic results, such as views and number of subscribers, was verified. Finally, a significant mediating role of eWOM in the relationship between user engagement and advertisement results was reported. The results of the current study are highly important for administrators of social media video channels, as they provide enough information on how to develop their promotional strategy and how to best manage the content they want to upload.
\end{abstract}

Keywords: Social Media, eWOM, YouTube, User Engagement.

\section{Introduction}

The rise of the Internet has created online forums, social media and communities which have increased the scope and implications of electronic Word-of-Mouth (eWoM) for customers and firms (Dwyer, 2007; Kozinets et al., 2010; Malthouse et al., 2013). The technological advances presented by social networking and the sites of firms result in more access to massive audiences, with the possibility of identifying and establishing regular, direct and customised interactions (Tahir M. Nisar et al., 2018). The resulting interactions, participation and sharing 
have led to several changes in the way market agents view and use technology, as well as provide new innovative methods for selling products and services (Dellarocas, 2003; Spaulding, 2010). While it is one thing to simply read or follow a social media post, making the decision to publicly contribute your reaction or opinion in response to the post indicates that an individual is more invested, aware and attentive (i.e. more engaged) with the content. This ability to act, interact and co-create online, as a key characteristic of online media, distinguishes it from other media platforms (Ksiazek et al., 2016). These researchers theorise a continuum of engagement, from exposure to interactivity, where more (quantity) and better (quality) ways to interact with content and with other users indicate deeper engagement. Given the possibility that consumers now directly interact with companies on social media, several important theoretical and empirical questions arise: What happens if consumers engage with a company on social media, such as commenting on its Facebook posts? Does it make a financial difference if consumers leave positive or negative comments on a company's social media posts? How can a company tell that its social media marketing is working? (Yoon et al., 2018). In general, it is important for a company with a social media channel to understand how the user engages with the content and if all this leads to positive word-of-mouth and the creation of new users and impressions.

YouTube is one of the largest media platforms used for music and video sharing. Researchers have examined a diverse set of consequences of eWoM, e.g. brand purchase probability (East, Hammond, and Lomax, 2008), a tendency to recommend (Liu, 2006), involvement (Muniz, and O'Guinn, 2001), product adoption (Algesheimer, and Wangenheim, 2006; Thompson and Sinha, 2008) and feedback on products and services (Grégoire, Laufer, and Tripp, 2010; Hennig-Thurau, 2004). Similarly, several studies have examined the antecedents of eWoM, e.g. affective characteristics of the message (Berger, and Milkman, 2012), relational factors (Chu, and Kim, 2011) and individual traits (Mowen, Park, and Zablah, 2007). The main objective of the current study is to examine the relationship between online user engagement and eWOM, also addressing the effects on user interaction advertisement results. Most of the existing literature has used either qualitative data (e.g. online texts) or questionnaires for their research. In contrast, in the current study, the data set has been extracted from original YouTube insights and represents objective values.

At the beginning, the paper examines the current state of research in the field of User Engagement and eWOM. In terms of the research method, a data set was extracted from original YouTube insights, so as to construct variables that represent the three main constructs: user engagement, eWOM and performance. After filtering the raw data set that came from YouTube insights, six main variables were extracted. eWOM (Shares), Engagement (Likes and Comments), Subscribers, Views and Ad Impressions have been put into the data set. Linear, multiple and regression with a mediation effect have been used as models to examine the role of both eWOM and Engagement and confirm the main hypothesis that eWOM grows exponentially when affected by the engagement a user has with the content. Moreover, it has 
been hypothesised that eWOM plays a significant role as a predictor in the number of subscribers and video views and as a mediator between User Engagement and the number of Advertisements Impressions. After confirming the initial hypotheses, the managerial implications the research has in a social media strategy and other organisations have been acknowledged, and future research topics, such as examining various combinations of social media channels, have been proposed.

\section{Literature Review}

\subsection{Brand and community engagement}

Brand engagement, as described by Mollen and Wilson (2010), is divided into consumer engagement: "the cognitive and affective commitment to an active relationship with the brand as personified by the website or other computer-mediated entities designed to communicate brand value"; and online brand engagement, which is far more expressive than online involvement, as it involves an interactive relationship between the customer and the product that he/she engages with.

By focusing on the user-brand engagement and how the brand marketing strategy affects customer behaviour, a theory states that engagement is an alignment between the customer and the goals of the firm (Van Doorn et al., 2010). Depicting this in the media industry, engagement is the willingness of both the brand and the fan of the brand to promote a positive feeling about a product. Brands with increased equity are more likely to accommodate higher levels of engagement (Van Doorn et al., 2010). High customer engagement can support brands to attract new customers and keep old customers (Wangenheim, and Bayón, 2007). Community engagement refers to the positive perceptions and feedback of members to their participation in activities held by the community (Algesheimer, Dholakia, and Herrmann, 2005). Such activities include both online activities (shares, likes, etc.) and offline activities (meeting in the physical world). Engagement in "a specialised, non-geographically bound, online community, based on social communications and relationships among a brand's consumers" (De Valck et al., 2009) could be considered as an important area of research, since the nature of online communities has still not been fully documented.

\subsection{Social Media Engagement}

In social media, engagement is a measure of an individual's cognitive response, personal or emotional connection and/or actions (Li, Berens, and de Maertelaere, 2013). After creating a social media post, engagement can occur in various ways (shares, likes, comments), contributing to the positive effect of a brand's product. Studies found a significant and positive 
relationship between a firm's social media marketing strategies and users' consumption and contribution of engagement, indicating the importance of social media marketing efforts in engaging users online (Mishra, 2019).

Acquiring user interest is vital for companies to expand their customer base, but it is also important to build up long-term "user loyalty" in order to prevent current customers from becoming dissatisfied and leaving (Kwon, and Wen, 2010). When interacting with customers over the Internet, Ryan and Jones (2012) suggest effective social media marketing is based on subtle consumer engagement and "leaving the sledgehammer approach to product promotion at home". This is mainly the result of successful customer care instead of forced advertising. Social media can assist in the the humanisation of a brand by connecting the product with customers and giving it a greater personality (Ellison, Steinfield, and Lampe, 2007). This is important, as social media is effective due to its two-way communication (Grieve et al., 2013). Chaffey and Ellis-Chadwick (2012) have also addressed the policy of brands that motivate social media users to express themselves and the success in using the wisdom of the crowd to answer their business problems.

Social media allows brands to discover exactly what customers are interested in and then use this information to tailor their products and services in order to meet those needs (Chen, Lu, Wang, Zhao, and Li, 2013; Choi, and Bazarova, 2015). They can be defined as the "umbrella term for the web-based software and services that allow users to come together online and exchange, discuss, communicate and participate in any form of social interaction" (Ryan, and Jones, 2012) and is one of the central features of Web 2.0, allowing for greater interaction between groups of people over the Internet (Chen et al., 2013; Cheung et al., 2011; Choi, and Bazarova, 2015). The emergence of social media has dramatically influenced marketing practices. Conventional, well-established marketing practices are not highly influential anymore and, in many cases, can backfire on a firm (Fournier, and Avery, 2011; Hennig-Thurau, Hofacker, and Bloching, 2013). Therefore, there is an ever-increasing need for updating the understanding of social media and to further develop knowledge which suits the imperatives of marketing in social media environments (Hennig-Thurau et al., 2013). One main challenge for marketers has been to see how their efforts can pay off and how their social media activities can influence important brand related variables (Hoffman, and Fodor, 2010).

Being a member of social media communities involves the use of various expressive activities, including posting content by oneself, reposting content from others, commenting on others' posts and messaging with others.

The content, valence and volume of conversations about a brand or a topic among consumers can be a good proxy for their preferences and hence a predictor of important performance variables, such as sales or the performance of a brand (Asur, and Huberman, 2010; Kumar, Bhaskaran, Mirchandani, and Shah, 2013; Sonnier, McAlister, and Rutz, 2011). Word-of-mouth (Kumar et al., 2013), positive and neutral comments (Sonnier et al., 2011) and 
the volume of content about a brand (Asur, and Huberman, 2010) are the main factors that affect them the most.

User behaviour can be categorised depending on the amount of content that someone produces during his interaction with a community. Past studies have indicated that posting frequency, the timing of posting, message modality and message appeal may influence the effectiveness of content management. In contrast to advertising on traditional media, such as $\mathrm{TV}$, which mainly aims to increase exposure, the marketing practice on social media often has dual goals: generating business exposure and managing brand relationship with consumers.

\subsection{WoM and eWoM}

Word-Of-mouth (WOM) has a major influence on consumer purchase decisions, especially in the case of new products for which awareness needs to be created and product information must be distributed on the consumer side (Engel, Kegerreis, and Blackwell, 1969; Katz, and Lazarsfeld, 1955; Mahajan, Muller, and Kerin, 1984). Particularly in experience goods like music, WOM has been tagged as the most crucial element of long-term success and is of minimal cost (De Vany, and Walls, 1999; Tirunillai, and Tellis, 2012).

Electronic Word-Of-Mouth (eWOM) has long been considered an influential marketing instrument (Bickart, and Schindler, 2001; Kumar, and Benbasat, 2006; Zhang, Craciun, and Shin, 2010). Consumers search for information posted by previous customers in order to make themselves comfortable before purchasing products or services (Pitta, and Fowler, 2005). The Internet has provided several appropriate platforms for eWOM, such as blogs, discussion forums, review websites, shopping websites and, lastly, social media websites (Cheung, and Thadani, 2012). Previous studies have found the influence of eWOM via these sources on the purchasing intentions of consumers (Bickart, and Schindler, 2001; Chan, and Ngai, 2011; Park, Lee, and Han, 2007; See-To, and Ho, 2014).

People are now able to exchange opinions and experiences about products or services with their friends and acquaintances on social media (Chu, and Kim, 2011; Kozinets, de Valck, Wojnicki, and Wilner, 2010). This reduced anonymity has the potential to make eWOM information more trustworthy and reliable (Chu, and Choi, 2011; Wallace, Walker, Lopez, and Jones, 2009). Indeed, since conversations in social media frequently refer to brands (Wolny, and Mueller, 2013), they are naturally influential on the purchasing intentions of consumers (Wang, Yu, and Wei, 2012). However, it is difficult to envisage all eWOM information as being influential on these intentions. Owing to the vast amount of information which consumers are exposed to, they need to critique and screen the information before using it.

The effects of electronic Word-Of-Mouth (eWOM) in virtual brand communities may also be significant (De Valck et al., 2009), as recommendations can occur at virtually no cost and spread rapidly, both within and beyond the virtual brand community. Chatterjee's (2001) findings support the applicability of specific WOM dynamics of traditional, offline contexts in online environments. For instance, consumers are more likely to search for, and accept, 
especially negative eWOM when they lack information and experience (Richins, and Bloch, 1991). Chevalier and Mayzlin (2006) also report that the number of readers of online book reviews may affect book sales, with negative reviews having a larger detrimental effect on sales than positive reviews. However, since positive eWOM is an important determinant of purchase intention (Farzin, and Fattahi, 2018), examining the triggers of positive eWOM calls for focused attention on more research.

Online channels now allow people to widely share their opinions and experiences on products through self-created content, with full geographical and temporal freedom (Jansen et al., 2009). Different studies have dealt with the motivations behind user contributions and have linked them to the wish to enhance influence and status, as well as the intention to help other members of a community by offering meaningful input (Hennig-Thurau et al., 2004). Research has further shown the tremendous influence of user-generated content (UGC) on consumer decision-making. Findings provide evidence that consumers tend to prefer product reviews from peers compared to reviews from professionals (Dellarocas, Zhang, and Awad, 2007; Smith, Menon, and Sivakumar, 2005).

Numerous studies have investigated the impact of eWOM on product sales in various contexts. Most of the current studies have examined the triggers to use eWOM in social media, either conceptually (Sijoria et al., 2018, 2019) or by using consumer surveys and opinions (Sijoria et al., 2019). Preliminary focus has been placed on assessing the effects of volume, valence and dispersion of UGC on consumer decisions. The volume describes the amount of generated content, whereas valence deals with the sentiment of this content (positive or negative). Dispersion is related to the variance across all generated content regarding a specific product/topic. Findings in the movie industry seem to be contradictory, where some studies find valence to be the most influential driver for the success of a movie instead of volume when focusing on the sequential product rollout typical for the entertainment industry (Chintagunta, Gopinath, and Venkataraman, 2010). The positive correlation between user and critic ratings is also rather low, encouraging the intention to investigate the impact of user-generated opinions instead of those by professionals (Dellarocas et al., 2007). Previous studies in the creative industry point towards a positive effect of the volume of eWOM on product sales (Duan, Gu, and Whinston, 2008; Yong, 2006). The increase of awareness through the high presence of a topic in online media positively affects sales. This relationship has been mostly addressed by looking at the volume of reviews about a product. Some recent studies limit this positive effect of eWOM volume, claiming there is no significant relationship or sales do explain volume and not the other way round (Jungho, and Byung-Do, 2013; Roschk, and Große, 2013). These studies suggest that volume can only influence the success of niche items, for which there is a higher need to create awareness, and this effect is only present in the first week after the release of a movie. 


\subsection{The role of user engagement in eWoM}

Consumer engagement with eWOM communication refers to customer behaviours that "go beyond transactions and may be specifically defined as a customer's behavioural manifestations that have a brand or firm focus, beyond purchase, resulting from motivational drivers" (Van Doorn et al., 2010, p. 254). This encompasses participation in eWOM-related activities, including initiating and sharing brand reviews, recommendations and referrals (Van Doorn et al., 2010). Such activities are derived through consumers' co-creation of value to self and others and inspire consumer experience (Brodie et al., 2011; Liou et al., 2016). This experience positively affects user engagement with eWoM, with its effects differentiating across communities for products and services and across their influence on 'likes' and 'comments' (Rossmann, Ranjan, Sugathan, 2016).

Taking an integrative approach, engagement was recently proposed to encompass various positively-valenced interactions between consumers and brands on three dimensions: cognitive, emotional and behavioural (Hollebeek, Glynn, and Brodie, 2014). The cognitive dimension refers to the level of brand-related thought processing and elaboration in a consumer/brand interaction. The emotional dimension relates to the extent of a desirable brand-related effect in a consumer/brand interaction. The behavioural brand engagement dimension accounts for the consumer activation process and refers to the time spent and effort invested by consumers during their brand-related activities (Hollebeek et al., 2014). In regard to digital social media, the behavioural dimension of consumer engagement with eWOM is of special interest, because SNS facilitates immediate and virtually costless engagement activities. Consumer engagement with eWOM on social media entails social interaction through receiving, commenting, liking or passing along product-related information to their social connections (Interactive Advertising Bureau, 2009). This often involves the consumer action of sharing experiences with others. This may result in a significant social benefit to consumers - the reinforcement of social relationships (Van Doorn et al., 2010). In general, it is hypothesised that content that creates user interaction, such as likes and shares, leads to eWOM. Each user, due to these actions, spreads his or her state to their network of friends and contacts.

\subsection{The effect of eWoM on performance}

As a rule, there is a push relation between positive comments, credibility and purchase intentions. A positive comment has a positive impact on credibility and influences purchase intention (Chih et al., 2013). The customers' positive eWOM is relevant to their brand purchases observed through sales performance (e.g. Babić et al., 2016; East et al., 2008; Pescher, Reichhart, and Spann, 2014). Similarly, the customers' negative eWOM is relevant to their retention performance, such as service disconnections (e.g. Vázquez-Casielles, SuárezÁlvarez, and del Río-Lanza, 2013). Xue and Phelps (2004) found that the eWOM platform to which a review is posted (an independent online forum versus a corporate website), by itself, 
did not influence brand attitudes. In the current study, it is hypothesised that content shared from users (eWOM) increases the number of posts views, as well as the number of subscribers, due to new visits. Finally, the eWOM could potentially enhance the income from advertisement due to the increasing of advertisement views (impressions).

\section{Method}

The data was obtained by using the insights of a YouTube music channel and represents actual inputs from user interaction. All insights were selected from a 6-year period. During this time, almost 500 music videos were uploaded. The channel administrators provided all the necessary authorisation to use the current data set.

\subsection{The channel}

Data was obtained from a YouTube channel specialising in electronic music, featuring songs from producers from all over the world, but mainly from South Africa. It began activity in 2011 and, at the time of writing, has uploaded more than 3000 videos with more than 190000 subscribers and 125000000 views.

\subsection{Procedure and Data set}

After receiving the appropriate authorisation from channel's administrators, an Excel file containing the raw data from the channel's insights was delivered to the researchers. The data set was cleaned of any unnecessary variables. The new data set consisted of the following variables: Views, Ad Impressions (as shown by the YouTube algorithm), Likes, Shares, Comments and Subscribers. Comments and Likes were considered as User Engagement variables, while Shares represented the eWoM variable. For the needs of the study, the data set with inputs from $242(\mathrm{~N}=242)$ different country cases was selected. In total, 83831 subscribers were included in the data. The final data set was then extracted into an SPSS statistics package.

\section{Results}

Simple linear regression analysis was conducted to predict (H1) the variability of electronic WoM based on the contribution of user engagement. Multiple regression analysis was conducted to examine $(\mathrm{H} 2)$ the variability of several subscribers and video views based on the contribution of eWoM. Finally, linear regression analysis with the mediation effect was conducted to examine (H3) the variability of Advertisements Impressions based on the 
contribution of user engagement by examining the mediation effect of eWoM. Regression analyses where obtained as the more appropriate to assess any significant prediction of the dependent variables (eWOM and performance metrics) from the independent ones (User Engagement and eWOM), as well as exploring the mediating prediction effect of eWOM.

Table 1.

Means and standard deviations

\begin{tabular}{|l|l|l|}
\hline Variables & Mean & Standard deviation \\
\hline User Engagement - Comments & 187.44 & 994.933 \\
\hline User Engagement - Likes & 1582.94 & 6565.326 \\
\hline eWOM - Shares & 1751.06 & 8126.231 \\
\hline Views & 268203.67 & 1343794.744 \\
\hline Subscribers & 346.41 & 1355.046 \\
\hline Ad Impressions & 70368.60 & 694727.402 \\
\hline
\end{tabular}

Linear regression analysis was used to test if user engagement elements significantly predicted eWoM based on video shares. The results of the regression indicated that the two predictors explained $92.2 \%$ of the variance $(\mathrm{R} 2=0.92, \mathrm{~F}(2,24)=1412.5, \mathrm{p}<0.001)$. It was found that number of comments significantly predicted eWOM $(\beta=0.25, p<0.001)$, as did the number of likes $(\beta=0.72, \mathrm{p}<0.001)$ (Table 2$)$.

\section{Table 2.}

Regression Coefficients 1

\begin{tabular}{|l|r|r|r|r|r|r|r|}
\hline \multirow{2}{*}{ Predictors } & Beta & Std. Error & t & \multirow{2}{*}{ Sig. } & \multicolumn{3}{|c|}{ Correlations } \\
\hline Comments & 0.252 & 0.491 & 4.188 & 0.000 & 0.936 & 0.261 & 0.076 \\
\hline Likes & 0.717 & 0.074 & 11.915 & 0.000 & 0.957 & 0.610 & 0.215 \\
\hline
\end{tabular}

Dependent Variable: Shares.

Multivariate regression analysis was used to test if eWoM based on video shares, significantly predicted number of subscribers and video views. The results of the analysis reported that the independent variable explained $79.3 \%$ of the variance of Subscribers $(\mathrm{R} 2=.79, \mathrm{~F}(1,24)=924.2, \mathrm{p}<.001)$ and $70.4 \%$ of the variance of video views $(\mathrm{R} 2=.70$, $\mathrm{F}(1,24)=573.6, \mathrm{p}<.001)$. It was indicated that eWoM significantly predicted Subscribers $(\beta=.89, \mathrm{p}<.001)$, and video views $(\beta=0.84, \mathrm{p}<.001)($ Table 3$)$. 
Table 3.

Regression Coefficients 2

\begin{tabular}{|c|c|c|c|c|c|c|c|}
\hline \multirow{2}{*}{$\begin{array}{l}\text { Dependent } \\
\text { variables }\end{array}$} & \multirow[b]{2}{*}{ Beta } & \multirow[b]{2}{*}{ Std. Error } & \multirow[b]{2}{*}{$\mathbf{t}$} & \multirow[b]{2}{*}{ Sig. } & \multicolumn{3}{|c|}{ Correlations } \\
\hline & & & & & Zero-order & Partial & Part \\
\hline \begin{tabular}{|l|} 
Views \\
\end{tabular} & 0.840 & 5.798 & 4.188 & 0.000 & 0.936 & 0.261 & 0.076 \\
\hline \begin{tabular}{|l|} 
Subscribers \\
\end{tabular} & 0.891 & 0.005 & 30.400 & \begin{tabular}{|l|}
0.000 \\
\end{tabular} & 0.891 & 0.891 & 0.891 \\
\hline
\end{tabular}

Finally, the mediating role of eWoM in the relationship between User Engagement and Advertisements Impressions was examined. Likes and Comments as independent variables were examined separately into two different tests. After completion of the Sobel tests, it resulted that eWOM does not play a significant mediating role in the Likes-Advertisement impressions relationship $(\mathrm{z}=1.19, \mathrm{p}>0.05)$. On the other hand, the results indicated that $\mathrm{eWoM}$ has a strong effect as a mediator in the Comments-Advertisement Impressions relationship $(\mathrm{z}=3.96$, $\mathrm{p}<0.001)$.

\section{Conclusion}

The current study tries to offer a more thorough view of the effect that eWOM and engagement have on the crucial variables of a social media brand. This is achieved by using an extensive dataset provided by the YouTube API of a channel with almost 200000 subscribers, more than 2000 videos and 6 years of operation. In contrast with other similar papers, the data set has been extracted from social media channel insights and represents actual values.

It has been considered that the objective of a YouTube channel is to generate more views that, in return, generate more advertisements, which provide the channel owner more income. In order to achieve this, a populated community must be developed, leading to the increase of eWOM and, with a larger user, engagement (Frick, Tsekauras, and Li, 2014). This simple conceptual model has been tested through a statistical analysis of the dataset, leading to the confirmation of our hypotheses.

Statistical analyses showed that user engagement elements significantly predicted eWOM, which represents the number of shares. The role of eWOM as a predictor of important outcomes - such as number of subscribers and video views - has also been examined. It has been found that eWOM explained a vast amount of both variables. Finally, the significant mediating role of WOM in the relationship between User Engagement and Advertisements Impressions has been reported.

The results are in line with literature that states that what consumers talk about can be a good proxy for their preferences and hence a predictor of important performance variables such as sales (Asur, and Huberman, 2010; Kumar, Bhaskaran, Mirchandani, and Shah, 2013; 
Sonnier et al., 2011). Many researchers showed that spreading WOM (Kumar et al., 2013), positive and neutral comments (Sonnier et al., 2011) and the volume of content about a brand (Asur, and Huberman, 2010) enhance the sales and performance of a brand. Consumer involvement with brand-related user-generated content enhances brand equity (Christodoulides, Jevons, and Bonhomme, 2012), and involvement in co-creation of value enhances the transfer of WOM and purchase intentions (See-To, and Ho, 2014). Finally, the current research outcomes support the findings of Rossmann et al. (2016), who reported that user engagement has a positive effect on eWOM for various brands.

\section{Managerial implications}

The results of the current study are highly important for companies or artists in the field of social media promotion, as they provide the interested parties with enough information on how to develop their promotion strategy and how to best manage the content they want to upload. Videos (or content in general) should create the need for the user (or client) to interact with the content or post. This leads to a larger number of likes, shares and comments, and then to an augmented number of views and thus advertisements.

\section{Future Research}

The results of the current study should not be generalised, as they represent insights only from a specific music YouTube channel. Users could possibly engage and interact in a different way through other social media platforms (such as Facebook or Instagram). The research on the subject could be expanded by analysing the effect that sponsored posts have on the content. This would enhance the ability to understand how paid promotion works on social media and would provide a better understanding on how the advertiser could meet the KPIs set. Furthermore, another point of interest could be an examination of the relationship between two social media platforms. Do the social media communities of the same brand interact with each other, and what is their correlation? With the rise and fall of various social media platforms, it is difficult for a brand to maintain its interest in all their platforms, so there should be a more insightful approach on brand community management. 


\section{References}

1. Algesheimer, R., and Wangenheim, F.V. (2006). A network based approach to customer equity management. Journal of Relationship Marketing, 5(1), 39-57. doi: https://doi.org/ 10.1300/J366v05n01_04.

2. Algesheimer, R., Dholakia, U.M., and Herrmann, A. (2005). The social influence of brand community: Evidence from European car clubs. Journal of marketing, 69(3), 19-34. doi: 10.1300/J366v05n01_04.

3. Asur, S., and Huberman, B.A. (2010, August). Predicting the future with social media. Proceedings of the 2010 IEEE/WIC/ACM International Conference on Web Intelligence and Intelligent Agent Technology-Volume 01. IEEE Computer Society, (pp. 492-499). doi: 10.1109/WI-IAT.2010.63.

4. Babić Rosario, A., Sotgiu, F., De Valck, K., and Bijmolt, T. H. (2016). The effect of electronic word of mouth on sales: A meta-analytic review of platform, product, and metric factors. Journal of Marketing Research, 53(3), 297-318. doi: 10.1509/jmr.14.0380.

5. Berger, J., and Milkman, K.L. (2012). What makes online content viral? Journal of marketing research, 49(2), 192-205. doi: 10.1509\%2Fjmr.10.0353.

6. Bickart, B., and Schindler, R.M. (2001). Internet forums as influential sources of consumer information. Journal of interactive marketing, 15(3), 31-40. doi: 10.1002/dir.1014.

7. Brodie, R.J., Hollebeek, L.D., Jurić, B., and Ilić, A. (2011). Customer engagement: Conceptual domain, fundamental propositions, and implications for research. Journal of service research, 14(3), 252-271. doi: 10.1177\%2F1094670511411703.

8. Chan, Y.Y., and Ngai, E.W. (2011). Conceptualising electronic word of mouth activity: An input-process-output perspective. Marketing Intelligence and Planning, 29(5), 488-516. doi: 10.1108/02634501111153692.

9. Chatterjee, P. (2001) Online Reviews: Do Consumers Use Them? Advances in Consumer Research, 28, 129-133.

10. Chen, A., Lu, Y., Wang, B., Zhao, L., and Li, M. (2013). What drives content creation behavior on SNSs? A commitment perspective. Journal of Business Research, 66(12), 2529-2535. doi: 10.1016/j.jbusres.2013.05.045.

11. Cheung, C.M., and Thadani, D.R. (2012). The impact of electronic word-of-mouth communication: A literature analysis and integrative model. Decision support systems, 54(1), 461-470. doi:10.1016/j.dss.2012.06.008.

12. Cheung, C.M., Chiu, P.Y., and Lee, M.K. (2011). Online social networks: Why do students use facebook? Computers in Human Behavior, 27(4), 1337-1343. doi: 10.1016/ j.chb.2010.07.028.

13. Chevalier, J.A., and Mayzlin, D. (2006). The effect of word of mouth on sales: Online book reviews. Journal of marketing research, 43(3), 345-354. doi: 10.1509\%2Fjmkr.43.3.345. 
14. Chih, W.H., Wang, K.Y., Hsu, L.C., and Huang, S.C. (2013). Investigating electronic wordof-mouth effects on online discussion forums: the role of perceived positive electronic word-of-mouth review credibility. Cyberpsychology, Behavior, and Social Networking, 16(9), 658-668. doi: 10.1089/cyber.2012.0364.

15. Chintagunta, P.K., Gopinath, S., and Venkataraman, S. (2010). The effects of online user reviews on movie box office performance: Accounting for sequential rollout and aggregation across local markets. Marketing Science, 29(5), 944-957. doi:10.1287/ mksc. 1100.0572 .

16. Choi, Y.H., and Bazarova, N.N. (2015). Self-disclosure characteristics and motivations in social media: Extending the functional model to multiple social network sites. Human Communication Research, 41(4), 480-500. doi: 10.1111/hcre.12053.

17. Christodoulides, G., Jevons, C., and Bonhomme, J. (2012). Memo to marketers: Quantitative evidence for change: How user-generated content really affects brands. Journal of advertising research, 52(1), 53-64. doi: 10.2501/JAR-52-1-053-064.

18. Chu, S.C., and Choi, S.M. (2011). Electronic word-of-mouth in social networking sites: A cross-cultural study of the United States and China. Journal of Global Marketing, 24(3), 263-281. doi: 10.1080/08911762.2011.592461.

19. Chu, S.C., and Kim, Y. (2011). Determinants of consumer engagement in electronic wordof-mouth (eWOM) in social networking sites. International Journal of Advertising, 30(1), 47-75. doi: 10.2501/IJA-30-1-047-075.

20. De Valck, K., Van Bruggen, G.H., and Wierenga, B. (2009). Virtual communities: A marketing perspective. Decision support systems, 47(3), 185-203. doi: 10.1016/ j.dss.2009.02.008.

21. De Vany, A., and Walls, W.D. (1999). Uncertainty in the movie industry: Does star power reduce the terror of the box office? Journal of cultural economics, 23(4), 285-318. doi: 10.1023/A:1007608125988.

22. Dellarocas, C. (2003). The digitization of word of mouth: promise and challenges of online feedback mechanisms. Management Science, 49(10), 1407-1424. doi: 10.1287/mnsc. 49.10.1407.17308.

23. Dellarocas, C., Zhang, X.M., and Awad, N.F. (2007). Exploring the value of online product reviews in forecasting sales: The case of motion pictures. Journal of Interactive Marketing, 21(4), 23-45. doi:10.1002/dir.20087.

24. Duan, W., Gu, B., and Whinston, A.B. (2008). Do online reviews matter? An empirical investigation of panel data. Decision support systems, 45(4), 1007-1016. doi: 10.1016/ j.dss.2008.04.001.

25. Dwyer, P. (2007). Measuring the value of electronic word of mouth and its impact in consumer communities. Journal of Interactive Marketing, 21(2), 63-79. doi: 10.1016/ j.ijresmar.2008.04.001. 
26. East, R., Hammond, K., and Lomax, W. (2008). Measuring the impact of positive and negative word of mouth on brand purchase probability. International journal of research in marketing, 25(3), 215-224. doi: 10.1016/j.ijresmar.2008.04.001.

27. Ellis-Chadwick, F., and Chaffey, D. (2012). Digital Marketing: Strategy, Implementation and Practice. Pearson.

28. Ellison, N.B., Steinfield, C., and Lampe, C. (2007). The benefits of Facebook "friends:" Social capital and college students' use of online social network sites. Journal of computermediated communication, 12(4), 1143-1168. doi: 10.1111/j.1083-6101.2007.00367.x.

29. Engel, J.F., Kegerreis, R.J., and Blackwell, R.D. (1969). Word-of-mouth communication by the innovator. Journal of Marketing, 33(3), 15-19. doi: 10.1177\%2F00222429 6903300303.

30. Farzin, M., and Fattahi, M. (2018). eWOM through social networking sites and impact on purchase intention and brand image in Iran. Journal of Advances in Management Research, 15(2), 541-553. doi: 10.1108/JAMR-05-2017-0062.

31. Fournier, S., and Avery, J. (2011). The uninvited brand. Business horizons, 54(3), 193-207. doi: 10.1016/j.bushor.2011.01.001.

32. Frick, T., Tsekauras, D., and Li, T. (2014). The times they are a-changin: Examining the impact of social media on music album sales and piracy. In Annual Meeting of the Academy of Management, Philadelphia, PA. doi: 10.5465/ambpp.2014.16984abstract.

33. Grégoire, Y., Laufer, D., and Tripp, T.M. (2010). A comprehensive model of customer direct and indirect revenge: Understanding the effects of perceived greed and customer power. Journal of the Academy of Marketing Science, 38(6), 738-758. doi: 10.1007/s11747009-0186-5.

34. Grieve, R., Indian, M., Witteveen, K., Tolan, G.A., and Marrington, J. (2013). Face-to-face or Facebook: Can social connectedness be derived online? Computers in human behavior, 29(3), 604-609. doi: 10.1016/j.chb.2012.11.017.

35. Hennig-Thurau, T., Gwinner, K.P., Walsh, G., and Gremler, D.D. (2004). Electronic wordof-mouth via consumer-opinion platforms: what motivates consumers to articulate themselves on the internet?. Journal of interactive marketing, 18(1), 38-52. doi: 10.1002/ dir. 10073.

36. Hennig-Thurau, T., Hofacker, C.F., and Bloching, B. (2013). Marketing the pinball way: understanding how social media change the generation of value for consumers and companies. Journal of Interactive Marketing, 27(4), 237-241. doi: 10.1016/ j.intmar.2013.09.005.

37. Hoffman, D.L., and Fodor, M. (2010). Can you measure the ROI of your social media marketing? MIT Sloan management review, 52(1), 41.

38. Hollebeek, L.D., Glynn, M.S., and Brodie, R.J. (2014). Consumer brand engagement in social media: Conceptualization, scale development and validation. Journal of interactive marketing, 28(2), 149-165. doi:10.1016/j.intmar.2013.12.002. 
39. Jansen, B.J., Zhang, M., Sobel, K., and Chowdury, A. (2009). Twitter power: Tweets as electronic word of mouth. Journal of the American society for information science and technology, 60(11), 2169-2188. doi: 10.1002/asi.21149.

40. Katz, E., Lazarsfeld, P.F., and Roper, E. (2017). Personal influence: The part played by people in the flow of mass communications. Routledge. doi: 10.4324/9781315126234.

41. Kozinets, R.V., De Valck, K., Wojnicki, A.C., and Wilner, S.J. (2010). Networked narratives: Understanding word-of-mouth marketing in online communities. Journal of Marketing, 74(2), 71-89. doi: 10.1509\%2Fjm.74.2.71.

42. Ksiazek, T.B., Peer, L., and Lessard, K. (2016). User engagement with online news: Conceptualizing interactivity and exploring the relationship between online news videos and user comments. New Media \& Society, 18(3), 502-520. doi: 10.1177/ 1461444814545073.

43. Kumar, N., and Benbasat, I. (2006). Research note: the influence of recommendations and consumer reviews on evaluations of websites. Information Systems Research, 17(4), 425-439. doi: 10.1287/isre.1060.0107.

44. Kumar, V., Bhaskaran, V., Mirchandani, R., and Shah, M. (2013). Practice prize winnercreating a measurable social media marketing strategy: increasing the value and ROI of intangibles and tangibles for hokey pokey. Marketing Science, 32(2), 194-212. doi: $10.1287 / \mathrm{mksc} .1120 .0768$.

45. Kwon, O., and Wen, Y. (2010). An empirical study of the factors affecting social network service use. Computers in human behavior, 26(2), 254-263. doi: 10.1016/j.chb. 2009.04.011.

46. Li, T., Berens, G., and de Maertelaere, M. (2013). Corporate Twitter channels: The impact of engagement and informedness on corporate reputation. International Journal of Electronic Commerce, 18(2), 97-126. doi:10.2753/JEC1086-4415180204.

47. Liou, D.K., Chih, W.H., Yuan, C.Y., and Lin, C.Y. (2016). The study of the antecedents of knowledge sharing behavior: The empirical study of Yambol online test community. Internet Research, 26(4), 845-868. doi: 10.1108/IntR-10-2014-0256.

48. Liu, Y. (2006). Word of mouth for movies: Its dynamics and impact on box office revenue. Journal of Marketing, 70(3), 74-89. doi:10.1509\%2Fjmkg.70.3.074.

49. Mahajan, V., Muller, E., and Kerin, R.A. (1984). Introduction strategy for new products with positive and negative word-of-mouth. Management Science, 30(12), 1389-1404. doi: $10.1287 /$ mnsc.30.12.1389.

50. Malthouse, E.C., Haenlein, M., Skiera, B., Wege, E., and Zhang, M. (2013). Managing customer relationships in the social media era: Introducing the social CRM house. Journal of Interactive Marketing, 27(4), 270-280. doi: 10.1016/j.intmar.2013.09.008.

51. Mishra, A.S. (2019). Antecedents of consumers' engagement with brand-related content on social media. Marketing Intelligence \& Planning, 37(4), 386-400. doi:10.1108/MIP-042018-0130. 
52. Mollen, A., and Wilson, H. (2010). Engagement, telepresence and interactivity in online consumer experience: Reconciling scholastic and managerial perspectives. Journal of business research, 63(9-10), 919-925. doi: 10.1016/j.jbusres.2009.05.014.

53. Mowen, J.C., Park, S., and Zablah, A. (2007). Toward a theory of motivation and personality with application to word-of-mouth communications. Journal of business research, 60(6), 590-596. doi: 10.1016/j.jbusres.2006.06.007.

54. Muniz, A.M., and O'guinn, T.C. (2001). Brand community. Journal of consumer research, 27(4), 412-432. doi:10.1086/319618.

55. Nisar, T.M., Prabhakar, G., Ilavarasan, P.V. and Baabdullah, A.M. (2019). Up the ante: electronic word of mouth and its effects on firm reputation and performance. Journal of Retailing and Consumer Services, 53. doi.org:10.1016/j.jretconser.2018.12.010.

56. Park, D.H., Lee, J., and Han, I. (2007). The effect of on-line consumer reviews on consumer purchasing intention: The moderating role of involvement. International journal of electronic commerce, 11(4), 125-148. doi: 10.2753/JEC1086-4415110405.

57. Pescher, C., Reichhart, P., and Spann, M. (2014). Consumer decision-making processes in mobile viral marketing campaigns. Journal of interactive marketing, 28(1), 43-54. doi: 10.1016/j.intmar.2013.08.001.

58. Pitta, D.A., and Fowler, D. (2005). Internet community forums: an untapped resource for consumer marketers. Journal of Consumer Marketing, 22(5), 265-274. doi: 10.1108/ 07363760510611699.

59. Richins, M.L., and Bloch, P.H. (1991). Post-purchase product satisfaction: Incorporating the effects of involvement and time. Journal of Business Research, 23(2), 145-158. doi: 10.1016/0148-2963(91)90025-S.

60. Roschk, H., and Grosse, S. (2013). Talking about films: Word-of-mouth behavior and the network of success determinants of motion pictures. Journal of Promotion Management, 19(3), 299-316. doi: 10.1080/10496491.2013.770810.

61. Rossmann, A., Ranjan, K.R., and Sugathan, P. (2016). Drivers of user engagement in eWoM communication. Journal of Services Marketing, 30(5), 541-553. doi:10.1108/JSM01-2015-0013.

62. Ryan, D. (2016). Understanding digital marketing: marketing strategies for engaging the digital generation. Kogan Page Publishers.

63. See-To, E.W., and Ho, K.K. (2014). Value co-creation and purchase intention in social network sites: The role of electronic Word-of-Mouth and trust-A theoretical analysis. Computers in Human Behavior, 31, 182-189. doi: 10.1016/j.chb.2013.10.013.

64. Sijoria, C., Mukherjee, S., and Datta, B. (2018). Impact of the antecedents of eWOM on CBBE. Marketing Intelligence \& Planning, 36(5), 528-542. doi:10.1108/MIP-10-20170221. 
65. Sijoria, C., Mukherjee, S., and Datta, B. (2019). Impact of the antecedents of electronic word of mouth on consumer based brand equity: a study on the hotel industry. Journal of Hospitality Marketing \& Management, 28(1), 1-27. doi:10.1080/19368623.2018.1497564.

66. Smith, D., Menon, S., and Sivakumar, K. (2005). Online peer and editorial recommendations, trust, and choice in virtual markets. Journal of interactive marketing, 19(3), 15-37. doi: 10.1002/dir.20041.

67. Sonnier, G.P., McAlister, L., and Rutz, O.J. (2011). A dynamic model of the effect of online communications on firm sales. Marketing Science, 30(4), 702-716. doi: 10.1287/ mksc. 1110.0642 .

68. Spaulding, T.J. (2010). How can virtual communities create value for business? Electronic Commerce Research and Applications, 9, 38-49. doi:10.1016/j.elerap.2009.07.004.

69. Thompson, S.A., and Sinha, R.K. (2008). Brand communities and new product adoption: The influence and limits of oppositional loyalty. Journal of marketing, 72(6), 65-80. doi:10.1509\%2Fjmkg.72.6.065.

70. Tirunillai, S., and Tellis, G.J. (2012). Does chatter really matter? Dynamics of usergenerated content and stock performance. Marketing Science, 31(2), 198-215. doi:10.1287/ mksc. 1110.0682 .

71. Van Doorn, J., Lemon, K.N., Mittal, V., Nass, S., Pick, D., Pirner, P., and Verhoef, P.C. (2010). Customer engagement behavior: Theoretical foundations and research directions. Journal of service research, 13(3), 253-266. doi: 10.1177\%2F1094670510375599.

72. Vázquez-Casielles, R., Suárez-Álvarez, L., and Del Rio-Lanza, A.B. (2013). The word of mouth dynamic: How positive (and negative) WOM drives purchase probability: An analysis of interpersonal and non-interpersonal factors. Journal of Advertising Research, 53(1), 43-60. doi: 10.2501/JAR-53-1-043-060.

73. Wallace, D., Walker, J., Lopez, T., and Jones, M. (2009). Do word of mouth and advertising messages on social networks influence the purchasing behavior of college students? Journal of Applied Business Research, 25(1), 101-9. doi:10.19030/jabr.v25i1.1052.

74. Wang, X., Yu, C., and Wei, Y. (2012). Social media peer communication and impacts on purchase intentions: A consumer socialization framework. Journal of interactive marketing, 26(4), 198-208. doi:10.1016/j.intmar.2011.11.004.

75. Wangenheim, F.V., and Bayón, T. (2007). The chain from customer satisfaction via wordof-mouth referrals to new customer acquisition. Journal of the Academy of Marketing Science, 35(2), 233-249. doi:10.1007/s11747-007-0037-1.

76. Wolny, J., and Mueller, C. (2013). Analysis of fashion consumers' motives to engage in electronic word-of-mouth communication through social media platforms. Journal of Marketing Management, 29(5-6), 562-583. doi: 10.1080/0267257X.2013.778324.

77. Xue, F., and Phelps, J.E. (2004). Internet-facilitated consumer-to-consumer communication: The moderating role of receiver characteristics. International journal of internet marketing and advertising, 1(2), 121-136. doi: 10.1504/IJIMA.2004.004016. 
78. Yoon, G., Li, C., Ji, Y., North, M., Hong, C., and Liu, J. (2018). Attracting Comments: Digital Engagement Metrics on Facebook and Financial Performance. Journal of Advertising, 47(1), 24-37. doi: 10.1080/00913367.2017.1405753.

79. Zhang, J.Q., Craciun, G., and Shin, D. (2010). When does electronic word-of-mouth matter? A study of consumer product reviews. Journal of Business Research, 63(12), 1336-1341. doi: 10.1016/j.jbusres.2009.12.011. 